(C) О.М. Волошин, О.В. Суздаленко, В.О. Губка, О.Г. Попова, 2020

УДК 616.5-002.44-02: 616.14-007.64-008.3/.5]-089.191

\title{
Порівняння ранньої та відкладеної ендовенозної корекції поверхневого рефлюксу у хворих із варикозними виразками
}

\author{
О.М. Волошин, О.В. Суздаленко, В.О. Губка, О.Г. Попова \\ Судинний центр АнгіоЛайф, Запоріжжя
}

\section{Реферат}

Варикозна хвороба (BХ) і синдром хронічної венозної недостатності (XBH) є одними з найбільш поширених захворювань серед населення розвинених країн. У ході дослідження проведено проспективний аналіз комплексного ендовенозного лікування 82 пацієнтів із декомпенсованими формами хронічної венозної недостатності. У результаті проведеного комплексного лікування у 97,5\% хворих венозні виразки повністю епітелізувались протягом року. Рання ендовенозна корекція поверхневого рефлюксу - ефективний, безпечний та доступний метод лікування хворих 3 декомпенсованими формами варикозної хвороби. Застосування ранньої ендовенозної корекції поверхневого рефлюксу призвело до повної епітелізації варикозних виразок у 78,2\% протягом перших 6 місяців комплексного лікування.

Ключові слова: варикозна хвороба, ендовенозна коагуляція.

Comparison early with deferred endovenous laser ablation for active venous leg ulcer O. Voloshyn, O. Suzdalenko, V. Hubka, O. Popova Angio Life Vascular Center, Zaporizhzhya

Venous leg ulceration (VLU) is one of the most predominate medical disorders worldwide and in the western hemisphere it affects around $1-2 \%$ of the general population and up to $5 \%$ of the elderly population. The prospective study of 82 patients with VLU who undergoing endovenous varicose veins ablation at the AngioLife Vascular Center. As a result of comprehensive treatment in $97.5 \%$ of patients with VLU completely healed during the year, but there were some differences, particularly in terms of healing and symptoms of CVD dynamics depending on how fast the endovenous superficial venous treatment has been provided. Early endovenous superficial venous ablation is an effective, safe and affordable method of treatment for patients with active varicose leg ulcers. Limitations of this study include lack of a control arm or a standardized intervention. In addition, data were not collected on the size of the ulcer and it is possible that small ulcers of short duration may have healed with continued compression and conservative treatment alone. Further randomized controlled studies are needed to confirm these findings.

Key words:varicoseveins, endovenouscoagulation.

Вступ. Варикозна хвороба (ВХ) і синдром хронічної венозної недостатності (ХВН) є одними 3 найбільш поширених захворювань серед населення розвинених країн та представляють значну медичну проблему як для пацієнтів, так і суттєве навантаження на систему охорони здоров'я [1]. За даними Міжнародного конгресу флебологів (2013), на різні форми ХВН страждають близько $35 \%$ працездатного населення і понад $50 \%$ населення пенсійного віку. У міру прогресування хронічної венозної недостатності розвиваються стійкі, тяжкі порушення мікроциркуляції, що призведе до виникнення трофічного дефекту шкіри нижніх кінцівок [2].

Трофічні виразки нижніх кінцівок є найбільш тяжким проявом хронічної венозної недостатності і призводять до значного погіршення якості життя пацієнтів [3]. Незважаючи на прогрес в діагностиці та лікуванні варикозної хвороби, венозні виразки залишаються частим ускладненням варикозних вен, трапляються у 1-2\% працездатного населення та досягають 4-5\% у осіб похилого віку. Основним та найбільш ефективним методом лікування пацієнтів 3 декомпенсованими формами варикозу $\epsilon$ хірургічний. Хірургічне лікування спрямоване на ліквідацію венозних рефлюксів і усунення варикозно змінених поверхневих вен [4]. Однак підготов- ка пацієнтів із трофічними виразками до відкритої операції вимагає певного часу з цілком зрозумілих причин, а саме - великих розмірів виразки та інфікованої поверхні шкіри. Тому актуальним $є$ питання вибору малоінвазивного методу лікування, який би влаштовував хірургів у плані скорочення терміну передопераційної підготовки пацієнтів.

Домогтися стійкого загоєння трофічних виразок тільки хірургічними методами вдається не часто. Тому доцільно застосування комбінації різних варіантів консервативного й оперативного лікування [3,4]. На думку багатьох дослідників, важливою умовою, необхідною для загоєння венозних виразок і запобігання їх рецидивів, $є$ застосування адекватної еластичної компресії нижніх кінцівок, що спрямована на нормалізацію венозної гемодинаміки, яка сприяє загоєнню до 80\% виразок протягом року [2]. Місцеве лікування венозних виразок не є основним компонентом, і вибір конкретних лікарських засобів залежить від особливостей раневого процесу і стану тканин, що оточують трофічний дефект.

На сьогоднішній день запропоновані різні тактичні підходи до радикального вирішення проблеми венозних трофічних виразок. Однак питання раннього ендовенозного усунення венозного рефлюксу і його вплив на динаміку трофічних змін у 
пацієнтів 3 декомпенсованими формами варикозу залишається без остаточної оцінки.

Мета дослідження: порівняти ефективність ранньої та відкладеної ендовенозної корекції поверхневого рефлюксу у хворих 3 декомпенсованими формами варикозної хвороби.

Об'єкт і методи дослідження. У ході дослідження проведено проспективний аналіз комплексного ендовенозного лікування 82 пацієнтів з декомпенсованими формами хронічної венозної недостатності стадії С6 за класифікацією СЕАР, які проходили амбулаторне лікування в судинному центрі “АнгіоЛайф” з квітня 2015 по травень 2019 року. Всі хворі були розподілені на дві групи: основна - 42 пацієнта та група контролю - 40 пацієнтів. В основній групі (n=42) процедура ендовазальної термооблітерації

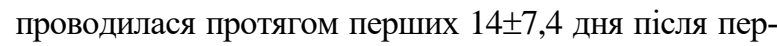
винного огляду, в групі контролю $(\mathrm{n}=40)$ процедура ЕВЛК проводилася через $60 \pm 12,3$ дня після консервативного етапу лікування. Етіологічним фактором розвитку хронічної венозної недостатності у всіх хворих був варикоз. Чоловіків було 27, жінок - 55.

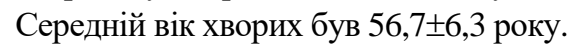

Усім пацієнтам до лікування проводилося ультразвукове дуплексне сканування глибоких та підшкірних вен стоячи, з метою верифікації причини хронічної венозної недостатності на апараті SIEMENS ACUSON S2000тм. Було взято посів флори 3 трофічної виразки, призначений компресійний трикотаж 2-го класу компресії, та прийом препаратів: Весел Дуе Ф 250MЕ 2 рази на добу протягом 4 місяців та Флебодіа 600 мг 1 раз на добу протягом 4 місяців. Ендоазальна термооблітерація (ЕВЛК) великої (ВПВ) та/або малої підшкірної вени (МПВ) проводилася за допомогою діодного лазера ELVES Ceralas Biolitec 1470нм або системи радіохвильової облітерації (PXO)Covidien VNUS RFG2 під УЗД-контролем і тумесцентною анестезією. Після процедури ЕВЛК частині хворих проводилась ехо-склеротерапія неспроможних перфорантних вен гомілки з використанням 1-3\% розчину полідоканолу у вигляді піни (Foam-Form) в пропорції з повітрям 1 до 2.

Оцінка ефективності комплексного лікування проводилася через 30, 60, 180 днів та через рік після первинного візиту, на підставі клінічних даних, а саме: динаміки загоєння трофічних виразок, інтенсивності болю, відчуття важкості в нижніх кінцівках до кінця дня, зниження толерантності до статичних навантажень та судом у литкових м'язах, також проводилося контрольне ультразвукове дуплексне сканування. Всі прояви ХВН, оцінювали в балах за візуальною аналоговою шкалою: 0 - відсутність симптомів; 1-2 - рідкісна поява, яка не впливає на загальний стан; 3-4 - часта поява, яка не впливає на загальний стан; 5-6 - виражений ступінь, який погіршує загальний стан, а також впливає на повсякденну активність та/або сон.

Отримані результати представляли у вигляді середньої (M) і стандартної помилки середнього (m). Внутрішньо групові відмінності оцінювали за допомогою двовибіркового $\chi 2$-тесту в залежності від виду даних у рамках програми StatPlus 2012. Статистично достовірними вважали відмінності між показниками при відхиленні нульової гіпотези і рівня значущості $\mathrm{p}<0,05$.

Результати досліджень та їх обговорення. Клінічна картина у більшості пацієнтів С6 класу характеризувалася значною виразністю всіх патологічних проявів ХВН, а саме - постійним болем, відчуттям важкості, судомами в гомілках, артрозом та в окремих випадках парціальною контрактурою гомілковостопного суглобу. За результатами проведеного УЗДГ-дослідження, в основній групі неспроможність клапанного апарату великої підшкірної вени (ВПВ) виявлена у 25 (59,5\%) хворих, малої підшкірної вени (МПВ) у $12(28,6 \%)$ хворих, ВПВ та МПВ у $5(11,9 \%)$ пацієнтів, при цьому неспроможність перфорантних вен у $31(73,8 \%)$ хворого. У групі контролю неспроможність клапанів ВПВ верифіковано у 22 (55\%) хворих, МПВ у 10 (25\%), ВПВ та МПВ у 8 (20\%) іперфорантних вен у $33(82,5 \%)$ пацієнтів.

У результаті проведеного комплексного лікування у 97,5\% хворих венозні виразки повністю епітелізувались протягом року, однак виявлені деякі відмінності, а саме - в термінах загоєння та динаміці симптомів ХВН в залежності від того, як швидко була проведена ендовенозна термооблітерація варикозних вен.

У 22 пацієнтів (52,3\%) основної групи,трофічні виразки повністю епітелізувались протягом 1-го місяця після ендовенозної термооблітерації (рис. 1Б), в групі контролю повне загоєння трофічних виразок на першому місяці спостереження відзначена лише у 5 пацієнтів (12,5\%). Динаміка загоєння венозних виразок, відображена у таблиці 1.

Аналізуючи дані діаграми слід відзначити, що у період 3 1-го по 3-й місяць спостереження в основній групі повне загоєння венозних виразок простежувалося у 15 пацієнтів $(35,7 \%)$ проти 11 хворих $(27,5)$ контрольної групи (рис. 1В). У період 3 3-го по 6-й місяць у 5 пацієнтів $(11,9 \%)$ основної групи було зафіксовано остаточне загоєння трофічних виразок проти 17 хворих $(42,5 \%)$ контрольної групи (p<0,05). В інтервалі з 6-го по 12-й місяць дослідження у всіх хворих основної групи не було зафіксовано жодних венозних виразок (рис. 1Г), проте в контрольній групі загоєння відбулося у решти 7 хворих (17,5\%).

У ході комплексного лікування 20 пацієнтів $(47,6 \%)$ основної групи потребували від 1 до 3 сеансів склеротерапії в період з 2-го по 5-й місяць спостереження, проти 15 пацієнтів $(37,5 \%)$ контрольної групи, яким проводилося від одного до двох сеансів склеротерапії в період 3 4-го по 9-й місяць спостереження. В ході всього періоду динамічного спостереження не було зафіксовано жодного випадку гнійно-інфекційного запалення в зонах пункцій підшкірних вен після ЕВЛК, РХО або склеротерапії. 
Динаміка загоєння венозних виразок у ході комплексного ендовенозного лікування поверхневого рефлюксу

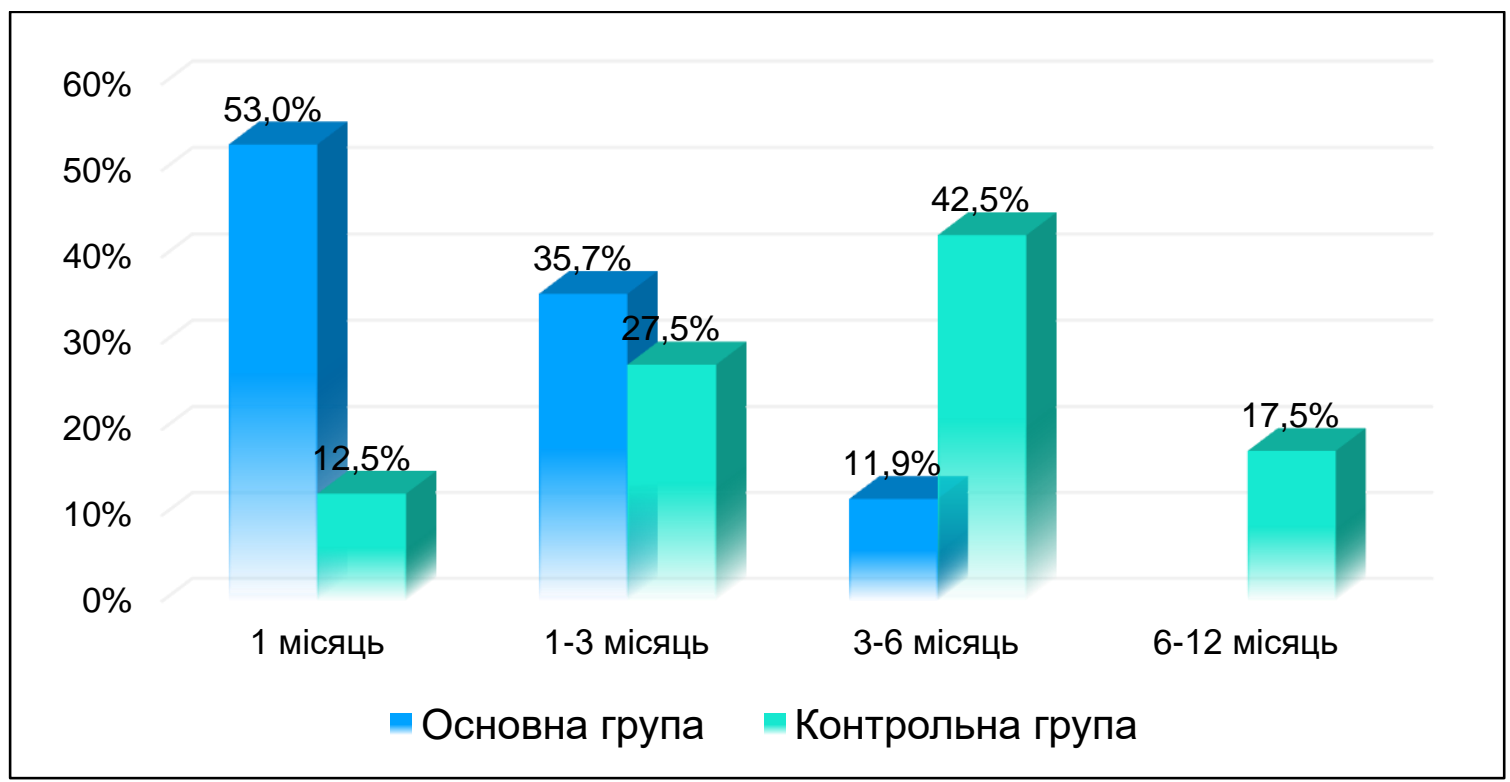

Таблиця 2

Динаміка зміни клінічних симптомів у пацієнтів основної (2А) та контрольної (2Б) групи

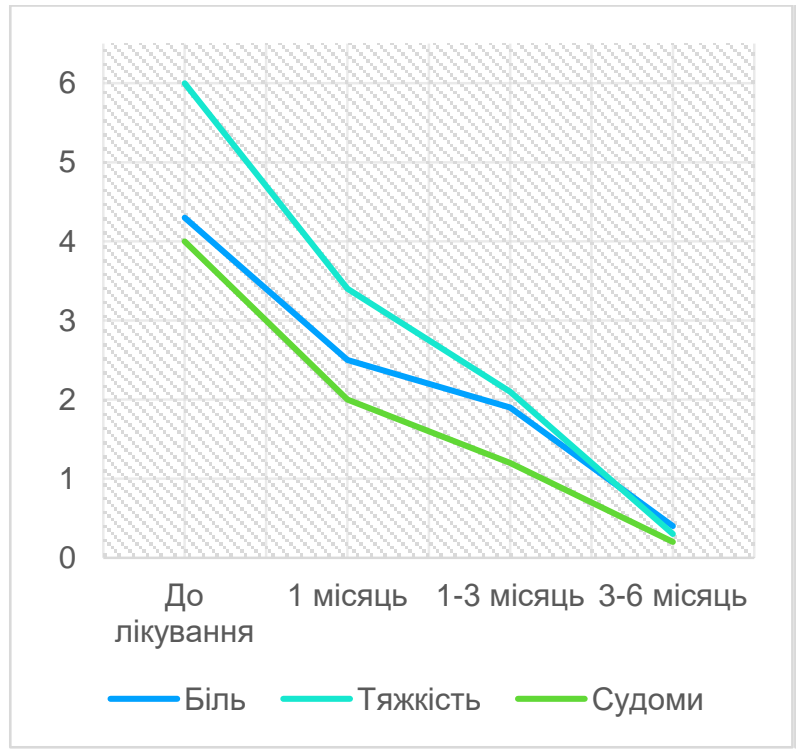

2A.

Із наведеної таблиці видно, що в процесі лікування простежується стійке зменшення виразності симптомів хронічної венозної недостатності в обох групах (відмінності між значеннями достовірні при р<0,05). Однак в основній групі, де була проведена рання ендовенозна термооблітерація варикозних вен, максимальне зменшення інтенсивності клінічних проявів ХВН виявлено вже на першому місяці лікування, в то час як в групі контролю період зменшення болю, важкості в гомілках та

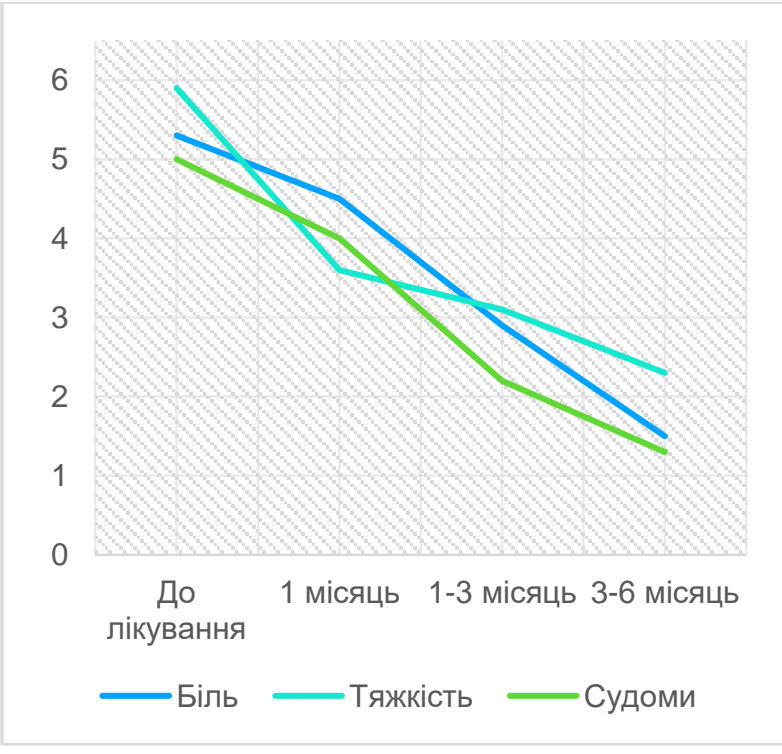

25.

судом відзначалося після третього місяця динамічного спостереження (таблиця 2). Слід відзначити, що с перших днів лікування всі хворі помітили позитивний вплив на зменшення симптомів ХВН після прийому препаратів ВесселДуе Ф 250MЕ та Флебодіа 600, щоденного використання компресійного трикотажу. Однак більшість хворих відзначало максимальне зменшення больового синдрому саме після проведення процедури ендовенозної термооблітерації. 


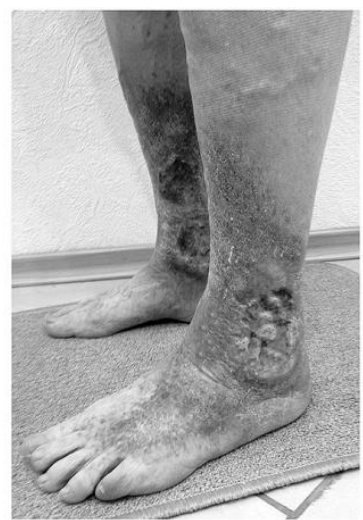

A.

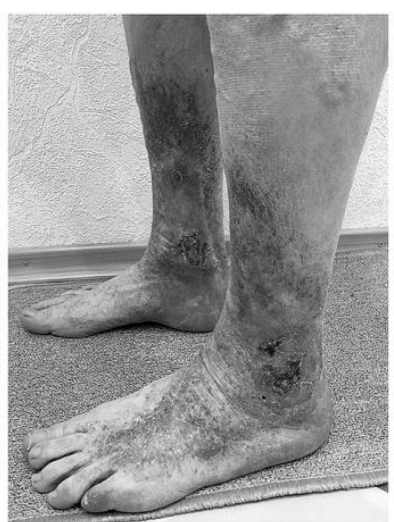

Б.

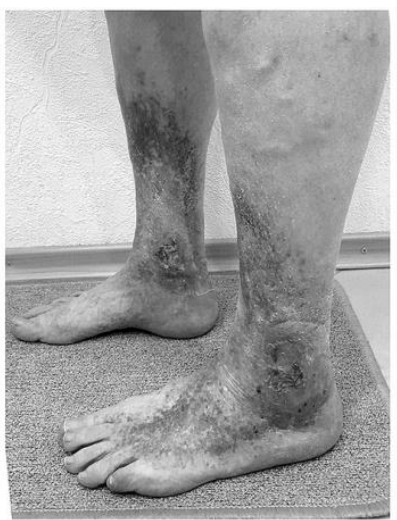

B.

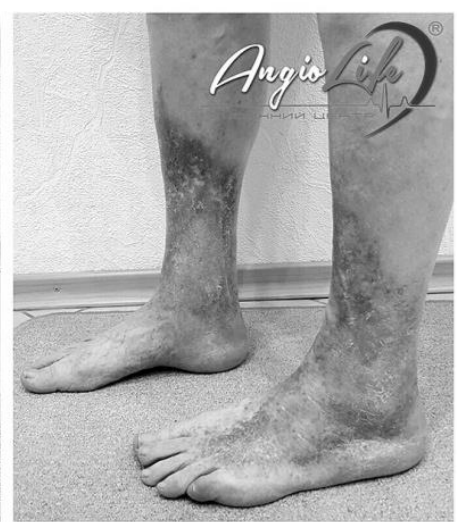

$\Gamma$.

Рис. 1. Динаміка загоєння трофічних виразок у пацієнтки 67 років з варикозною хворобою, ХВН СЕАР С 6 ст. (А - до лікування, Б - через 1 місяць, В - через 3 місяці, Г - через півроку).

Протягом дванадцятимісячного спостереження за хворими обох груп, у $1(2,4 \%)$ пацієнта основної групи та 3 (7,5\%) пацієнтів групи контролю зареєстровано рецидивне “відкриття" венозної виразки. Слід відзначити, що причиною рецидиву трофічних виразок у всіх хворих імовірно було недотримання компресійного режиму та зневага консервативного лікування.

При контрольному ультразвуковому дуплексному дослідженні у всіх хворих було верифіковано повна оклюзія неспроможних поверхневих вен, які були причиною виникнення хронічної венозної недостатності.

Згідно з основною теорією виникнення трофічних змін шкіри при хронічній венозній недостатності, основною причиною появи венозних виразок є важкі гемодинамічні зміни на макро- та мікроциркуляторному рівні, що призводить до виникнення запальної реакції [2]. При цьому провідним макрогемодинамічним чинником $\epsilon$ поверхневий вертикальний рефлюкс крові, пов'язаний 3 клапанною недостатністю в системі ВПВ та МПВ нижніх кінцівок. Важливу роль відіграє також горизонтальний рефлюкс, тобто неспроможність клапанів перфорантних вен, однак виходячи з результатів проведеного дослідження, менш ніж $47 \%$ хворим знадобилася склеротерапія перфорантних вен для загоєння трофічних виразок у всіх інших достатньо було усунути вертикальний рефлюкс. Отже, основою в лікуванні венозних трофічних виразок $є$ корекція патологічних рефлюксів, яку можна здійснювати навіть при наявності великих трофічних дефектів шкіри за допомогою малоінвазивних ендовеноз- них методів термокоагуляції. Очікувати повної санації та загоєння трофічних виразок тільки від консервативного методу лікування не є раціональним і тільки подовжує період до хірургічного етапу лікування.

При аналізі результатів лікування 3 даними літератури, слід зазначити, що схожі результати були отримані в рандомізованому клінічному досліджені EarlyVenousRefluxAblation (EVRA) trial, що проводилося у Великобританії [6]. У результаті дослідження було доведено, що рання ендовенозна коагуляція поверхневого венозного рефлюксу призвела до більш швидкого загоєння венозних виразок, ніж відкладена ендовенозна абляція. У той же час, результати рандомізованого дослідження ESCHAR [5], де порівнювалась хірургічна корекція поверхневого венозного рефлюксу 3 виключно компресійною терапією, показала, що хірургічна корекція не покращує загоєння виразки, але знижує ризик рецидиву виразки на чотири роки. Для виявлення найбільш ефективного методу лікування хворих $з$ декомпенсованими формами варикозної хвороби необхідно проведення подальших клінічних досліджень з оцінкою віддалених результатів лікування, та методами профілактики рецидивів.

Висновки. 1. Рання ендовенозная корекція поверхневого рефлюксу - ефективний, безпечний та доступний метод лікування хворих $з$ декомпенсованими формами варикозної хвороби.

2. Застосування ранньої ендовенозної корекції поверхневого рефлюксу привело до повної епітелізації варикозних виразок у 78,2\% протягом перших 6 місяців комплексного лікування.

Інформація про конфлікт інтересів. Автори заявляють про відсутність конфлікту інтересів при виконанні наукового дослідження та підготовці даної статті.

Інформація про фінансування. Автори гарантують, що вони не отримували жодних винагород у будь-якій формі, здатних вплинути на результати роботи.

Особистий внесок кожного автора у виконання роботи:

Волошин О.М. - розробка концепції і дизайну дослідження, аналіз отриманих даних, редагування, статистична обробка даних. 
Суздаленко О.В. - збір матеріалу дослідження, розробка дизайну дослідження, аналіз отриманих даних.

Губка В.О. - збір матеріалу дослідження, аналіз отриманих даних, підготовка тексту статті.

Попова О.Г.- збір матеріалу дослідження, аналіз отриманих даних, підготовка тексту статті.

\section{Список використаної літератури}

1. Eberhardt R.T., Raffetto J.D. Chronic venous insufficiency. Circulation. 2014;130:333-346.

2. Vlajinac H, Marinkovic J, Maksimovic M, Radak D. Factors related to venous ulceration: a cross-sectional study. Angiology2014; 65: 824-830.

3. Brittenden J, Cotton SC, Elders A, etal. A randomized trialcomparing treatments for varicose veins. N Engl J Med 2014;371:1218-1227.

4. Singer AJ, Tassiopoulos A, Kirsner RS. Evaluation and managemen tof lower-extremityulcers. N Engl J Med 2017;377:1559-1567.

5. Gohel MS, Barwell JR, Taylor M, etal. Long term results of compression therapy a lone versus compressionplus surgery in chronic venous ulceration (ESCHAR): randomised controlled trial. BMJ. 2007;335:83.

6. Gohel MS, Heatley F, Liu X, etal. A Randomized Trial of Early Endovenous Ablationin Venous Ulceration. N Engl J Med. 2018 May 31;378(22):2105-2114.

Стаття надійшла до редакції: 24.0.2020 р. 